\title{
Effects of lactic acid bacteria silage inoculation on methane emission and productivity of Holstein Friesian dairy cattle
}

\author{
J. L. Ellis, ${ }^{*} \dagger^{1}$ I. K. Hindrichsen, $\ddagger$ G. Klop, ${ }^{*}$ R. D. Kinley, ${ }^{*}$ N. Milora, $\ddagger$ A. Bannink, $\S$ and J. Dijkstra* \\ *Animal Nutrition Group, Wageningen University, Wageningen $6700 \mathrm{AH}$, the Netherlands \\ †Centre for Nutrition Modelling, Department of Animal and Poultry Science, University of Guelph, Guelph N1G 2W1, ON, Canada \\ ‡Chr. Hansen A/S, Bøge Allé 10-12, 2970 Hørsholm, Denmark \\ §Wageningen UR Livestock Research, Wageningen $6700 \mathrm{AH}$, the Netherlands
}

\begin{abstract}
Inoculants of lactic acid bacteria (LAB) are used to improve silage quality and prevent spoilage via increased production of lactic acid and other organic acids and a rapid decline in silage $\mathrm{pH}$. The addition of LAB inoculants to silage has been associated with increases in silage digestibility, dry matter intake (DMI), and milk yield. Given the potential change in silage and rumen fermentation conditions accompanying these silage additives, the aim of this study was to investigate the effect of LAB silage inoculants on DMI, digestibility, milk yield, milk composition, and methane $\left(\mathrm{CH}_{4}\right)$ production from dairy cows in vivo. Eight mid-lactation Holstein-Friesian dairy cows were grouped into 2 blocks of 4 cows (multiparous and primiparous) and used in a $4 \times 4$ double Latin square design with 21 -d periods. Methane emissions were measured by indirect calorimetry. Treatments were grass silage (mainly ryegrass) with no inoculant (GS), with a long-term inoculant (applied at harvest; GS+L), with a short-term inoculant (applied $16 \mathrm{~h}$ before feeding; GS+S), or with both long and short-term inoculants $(\mathrm{GS}+\mathrm{L}+\mathrm{S})$. All diets consisted of grass silage and concentrate $(75: 25$ on a dry matter basis). The long-term inoculant consisted of a 10:20:70 mixture of Lactobacillus plantarum, Lactococcus lactis, and Lactobacillus buchneri, and the short-term inoculant was a preparation of Lc. lactis. Dry matter intake was not affected by long-term or short-term silage inoculation, nor was dietary neutral detergent fiber or fat digestibility, or $\mathrm{N}$ or energy balance. Milk composition (except milk urea) and fat and protein-corrected milk yield were not affected by longor short-term silage inoculation, nor was milk microbial count. However, milk yield tended to be greater with long-term silage inoculation. Methane expressed in units of grams per day, grams per kilogram of DMI,
\end{abstract}

Received December 11, 2015.

Accepted May 15, 2016.

${ }^{1}$ Corresponding author: jennifer.st-pierre@wur.nl grams per kilogram of milk, or grams per kilogram of fat and protein-corrected milk yield was not affected by long- or short-term silage inoculation. However, $\mathrm{CH}_{4}$ expressed in units of kilojoules per kilogram of metabolic body weight per day tended to be greater with long-term silage inoculation. Results of this study indicate minimal responses in animal performance to both long- and short-term inoculation of grass silage with LAB. Strain and dose differences as well as different basal silages and ensiling conditions are likely responsible for the lack of significant effects observed here, although positive effects have been observed in other studies.

Key words: lactating cows, lactic acid bacteria, silage inoculant, methane

\section{INTRODUCTION}

Microbial silage inoculants such as lactic acid bacteria $(\mathbf{L A B})$ are used to improve silage fermentation and prevent spoilage of ryegrass and maize silages through increased organic acid production, mainly lactic acid (LA) and acetic acid, and a more rapid $\mathrm{pH}$ decline (Muck, 2013). Although plants contain native LAB, the number of viable LAB on forage can be insufficient and delay the decline in $\mathrm{pH}$ during ensiling, allowing greater loss of nutrients, other microbes to dominate fermentation, or both. Common LAB used for silage inoculation include homofermentative species such as Lactobacillus plantarum, Enterococcus faecium, and Pediococcus spp. Ensiling with these LAB results in conversion of water-soluble carbohydrate (WSC) to LA and a rapid decline in silage $\mathrm{pH}$ under anaerobic conditions (McDonald et al., 1991), which helps to prevent the development of clostridia, yeasts, molds, and fungi (Muck, 2013). Nutritionally, because of a more rapid $\mathrm{pH}$ decline, $\mathrm{LAB}$ inoculants tend to reduce the ammonia $\mathrm{N}$ content of silage via reduced fermentation of AA and reduced protein breakdown, as well as improved DM recovery (McDonald et al., 1991; Spoelstra, 1991; Henderson, 1993). Other heterofermentative LAB 
(e.g., Lactobacillus buchneri) that grow more slowly and produce a greater concentration of acetic acid are also often included and are typically inhibitory to fungi and preserve silage susceptible to spoilage upon exposure to air (e.g., Driehuis et al., 1999).

The use of LAB silage inoculants has been associated with increases in DMI, digestibility, and milk yield, although the mechanism remains convoluted (Weinberg and Muck, 1996; Weinberg et al., 2003; Ando et al., 2006). In addition, LAB have also been postulated as a potential probiotic with mastitis mitigation potential (e.g., Fang et al., 1996). Across all effects, results appear to be strain, dose, and silage specific. For example, an early meta-analysis (Muck and Kung, 1997) demonstrated positive responses in DMI to microbial inoculants $28 \%$ of the time, in body weight gain $53 \%$ of the time, and in milk production $47 \%$ of the time, based on literature from 1990 to 1995. Several hypotheses exist on the cause of improved animal performance, when observed, including (1) changes in the chemical composition of the silage, (2) inhibition of detrimental microbes and the production of toxins (e.g., bacteriocins; Gollop et al., 2005), and (3) interaction of LAB with rumen microbes and alteration of rumen fermentation (Fellner et al., 2001; Weinberg et al., 2003). The hypothesis for mastitis mitigation generally revolves around reduction of milk $\mathrm{pH}$ and competition for nutrients with detrimental bacteria (e.g., Fang et al., 1996), but the pathway by which oral LAB probiotics may reach the mammary gland is uncertain and at times convoluted (Fernández et al., 2013).

Nutritional or microbial changes within the rumen may also affect enteric methane $\left(\mathrm{CH}_{4}\right)$ production. Methane is a greenhouse gas produced as the result of enteric fermentation in the ruminant digestive tract, representing an energetic loss of 2 to $12 \%$ (Ellis et al., 2008). Globally, enteric fermentation from domestic ruminants accounts for $\sim 6.0 \%$ of the global anthropogenic $\mathrm{CO}_{2}$ equivalent production (FAOSTAT, 2013). Improving forage (either fresh or conserved) quality and digestibility is among the most effective mitigation strategies to decrease $\mathrm{CH}_{4}$ emission intensity $\left(\mathrm{CH}_{4}\right.$ per unit product; e.g., Hristov et al., 2013), which makes examining the potential impact of silage inoculants relevant. So far, several in vitro studies have suggested reductions in total gas production [Muck et al. (2007) using alfalfa silage and considering 14 individual and mixed LAB treatments] or $\mathrm{CH}_{4}$ production [Cao et al. (2010), using whole-crop rice silage with $L$ b. plantarum; Cao et al. (2011), using vegetable residue silage with Lb. plantarum] without changes in digestibility. However, not all in vitro studies have reported reductions in $\mathrm{CH}_{4}$ [Contreras-Govea et al. (2011), using alfalfa and corn silage, with individual and mixed LAB treat- ments], likely pointing to strain and inoculant differences, substrate differences, or in vitro methodology differences. Indeed, Ellis et al. (2016) found that LAB silage inoculants in vitro were effective on grass silage and not corn silage, and that some strains increased but others decreased (or did not change) total gas production, $\mathrm{CH}_{4}$ production, or DM digestibility.

Based on these in vitro results, the purpose of this study was to examine in vivo the long-term use (applied at harvesting, a 10:20:70 $\mathrm{cfu} / \mathrm{g}$ product ratio of Lb. plantarum, Lc. lactis, and Lb. buchneri) and shortterm use (applied $16 \mathrm{~h}$ before feeding, Lc. lactis as a probiotic) of LAB inoculants applied to grass silage for its effects on $\mathrm{CH}_{4}$ emission, DMI, diet digestibility, milk yield, milk composition, and milk microbial changes. The long-term inoculant was applied to examine potential effects due to changes in silage fermentation and silage composition, and the short-term inoculant was applied to examine any direct probiotic effects. We hypothesized that LAB may have direct or indirect $\mathrm{CH}_{4}$ mitigation potential in vivo when applied to grass silage fed to dairy cattle.

\section{MATERIALS AND METHODS}

This study was conducted at the Carus animal facility at Wageningen University, Wageningen, the Netherlands, in accordance with Dutch law and approved by the Institutional Animal Care and Use Committee of Wageningen University (Wageningen, the Netherlands).

\section{Cows, Experimental Design, and Diets}

Eight mid-lactation Holstein-Friesian dairy cows were grouped into 2 blocks of 4 cows and used in a $4 \times 4$ double Latin square design (21-d periods). Cows within blocks were matched for age, parity, stage of lactation, and milk production. The cows in block 1 (multiparous, average $4.5 \pm 0.25$ lactations) averaged $95 \pm 18.0$ DIM at the start of the experiment with an average BW of $676 \pm 20.2 \mathrm{~kg}$, and the cows in block 2 (primiparous) averaged $112 \pm 2.0$ DIM at the start of the experiment with an average BW of $521 \pm 9.4 \mathrm{~kg}$. Prior to the onset of the experiment, animals were group-housed for $7 \mathrm{~d}$ and fed a regular dairy ration while acclimatizing to the experimental location. Periods for blocks 1 and 2 were staggered by $4 \mathrm{~d}$ to facilitate measurements with the 4 individual climate respiration chambers available.

The experimental diet consisted of $75 \%$ grass silage (mainly Lolium perenne) and 25\% concentrate mixture [concentrate, $\mathrm{g} / \mathrm{kg}$ product basis: 242 maize, 64 wheat, 10 linseed, 84 palm kernel expeller, 34 formaldehydetreated rapeseed meal, 72 rapeseed meal, 259 formaldehyde-treated soybean meal, 100 beet pulp, 14.4 lime, 2.8 
salt, 50 molasses, 35 vinasse, 5.0 urea, 12.5 Mervit 2019 Cattle CPL (commercial premix; Nuscience, Utrecht, the Netherlands), 10 Rupromin balance (commercial premix; Provimi, Rotterdam, the Netherlands), 5.0 Mervit 2325 Sporavit (commercial premix; Nuscience)]. Treatments were based on feeding grass silage with or without a long-term and short-term LAB inoculation as follows: (1) control grass silage with no inoculation (GS), (2) grass silage inoculated with LAB at the time of grass harvesting (long-term inoculant; GS+L), (3) grass silage plus a LAB inoculant applied $16 \mathrm{~h}$ before feeding (short-term inoculant; GS+S), and (4) grass silage plus both the short-term and long-term LAB inoculants $(\mathbf{G S}+\mathbf{L}+\mathbf{S})$.

The grass for the experimental silages was harvested from a 10-ha plot of diploid perennial ryegrass ( L. perenne) cultivars of intermediate- and late-heading type (36\% each) and timothy grass (Phleum pratense; $28 \%$ ); for further details, see Warner et al. (2016). The grass mixture was a second-cut fall harvest with visible onset of crown rust (Puccinia coronata). Regrowth period was 6 wk. The grass was cut on the afternoon of September 4, 2012, left to wilt $1 \mathrm{~d}$, and then inoculated and baled (chopped to $4 \mathrm{~cm}$ ) using a Krone Big Pack 1270 XC (Krone, Spelle, Germany). Bales were wrapped in the field using stretch film (Visscher-Holland Megastretch stretch film, Steenwijk, the Netherlands; $750 \mathrm{~mm}$ wide and $25 \mu \mathrm{m}$ thick) in 16 turns of the bale with a $50 \%$ overlap. The grass DM at time of harvest was $45 \%$. Control grass (no inoculation; only water applied) was baled first to avoid contamination with the LAB inoculant, and bales were collected from grass spaced across the entire plot. For distribution of the LAB inoculant into the treated bales, a tractor mounted 400-L tank was used, and the inoculant was added directly to the water immediately before baling commenced. The hose of the tank was connected to a boom containing 2 nozzles, the boom was mounted slightly above the pickup of the baler, and the nozzles were directed slightly into the baler. Based on calibration data, an application rate of $0.61 \mathrm{~L}$ of liquid was applied per metric tonne of fresh forage. The control grass received an equal amount of water applied to ensure identical handling. Both control and treated bales were then stored outside for a minimum of $7 \mathrm{mo}$, until the onset of the trial on April 1, 2013.

The long-term inoculant was prepared by Chr. Hansen (Hørsholm, Denmark) as a powdered mixture of 10:20:70 (cfu/g of product) Lb. plantarum (6072), Lc. lactis (O-224), and Lb. buchneri (LB1819), respectively. The inoculant was applied in a water solution during grass harvest to achieve the standard of $1.5 \times 10^{5} \mathrm{cfu} / \mathrm{g}$ of grass as applied in current practice. Generally, an inoculation rate of $10^{5}$ to $10^{6}$ viable cells per gram of crop is sufficient for the inoculant LAB to overwhelm the epiphytic LAB and become the predominant population in the silage (Weinberg and Muck, 1996). The short-term inoculant, also prepared by Christian Hansen, was a powdered preparation of Lc. lactis (SR3.54). The short-term inoculant was applied to the grass silage in a water solution $16 \mathrm{~h}$ before morning feeding to obtain an intake of $5 \times 10^{9} \mathrm{cfu} / \mathrm{cow}$ per day. The short-term inoculant was only applied to the morning feed, which was restricted to $95 \%$ of ad libitum morning intake to ensure complete consumption of the LAB offered. The afternoon feed was ad libitum and hence intake remained ad libitum on a daily basis. Cows were housed in individual tie-stalls or individual respiration chambers during the full course of the experiment. Drinking water was provided ad libitum during the entire experiment.

\section{Methane Measurement}

In each 21-d period, $17 \mathrm{~d}$ of adaptation to the experimental diet was allowed, during which cows were individually housed in tie-stalls (Carus Research Facilities, Wageningen University, Wageningen, the Netherlands). From d 18 (1500 h) through d $22(0900 \mathrm{~h})$, animals were individually housed in 1 of 4 identical climate respiration chambers (CRC) at the Carus Research Facilities. A detailed description of the Wageningen University CRC system has recently been given by van Gastelen et al. (2015). Briefly, in each CRC (volume of $35 \mathrm{~m}^{3}$ ) relative humidity was maintained at $70 \%$ and temperature at $16^{\circ} \mathrm{C}$, and cows were exposed to $16 \mathrm{~h}$ of light per day. The lighting regimens were identical between the tie-stall barn and the CRC, and a night light was on between 2230 and $0530 \mathrm{~h}$. The ventilation rate was $42 \mathrm{~m}^{3} / \mathrm{h}$ per compartment, and inlet and exhaust air of each compartment was sampled at 10-min intervals. Gas concentrations and ventilation rates were corrected for pressure $(101.3 \mathrm{kPa})$, temperature $(273.15 \mathrm{~K})$, and humidity $(65 \%)$ to arrive at standard temperature pressure dew point volumes of inlet and exhaust air. Staff entered each CRC compartment twice daily at 0600 and $1600 \mathrm{~h}$ for approximately $30 \mathrm{~min}$ for milking and feeding. The gas measurements during the opening of the CRC were not used for data analysis. Cows were weighed immediately upon entering and just before leaving the CRC on a built-in scale in each chamber. Measurement of $\mathrm{CH}_{4}$ production, diet digestibility, energy and $\mathrm{N}$ balance, feed intake, milk production, and milk composition as well as metabolites in blood and the microbial composition of milk were taken during the chamber period. 


\section{Sampling and Measurements}

Feed Intake, Digestibility, and Balance Data. Silage and concentrate samples were collected during the measurement period in the CRC and pooled by period. Orts were collected each morning and afternoon and stored at $4^{\circ} \mathrm{C}$, pooled per cow during the measurement period, and stored at $-20^{\circ} \mathrm{C}$ pending analyses. Excreta (feces plus urine) were quantitatively collected from the CRC per cow after the measurement period and homogenized, and subsamples of $\sim 500 \mathrm{~mL}$ were stored at $-20^{\circ} \mathrm{C}$. Respiration gases and condensed water from the CRC were collected and stored at $4^{\circ} \mathrm{C}$ pending analyses. While cows were in the chambers, total collection of feed refusals, milk, and manure was conducted so that $\mathrm{N}$ and energy balance could be determined. Assuming that urine does not contain significant amounts of NDF and fat, this collection also allowed determination of NDF and fat digestibility.

Milk Production and Milk Composition. Cows were milked twice daily at 0600 and $1600 \mathrm{~h}$ in the CRC, and milk production was recorded at each milking. Milk was collected twice daily during milkings. A milk sample $(10 \mathrm{~mL})$ of each milking was collected in a tube containing sodium azide $(5 \mu \mathrm{L})$ for preservation and analysis for fat, protein, and lactose content and cell count, and milk samples for fatty acid (FA) analysis were collected with the same procedure but pooled per cow per period. Milk samples were also taken at each milking ( $5 \mathrm{~g} / \mathrm{kg}$ of milk), pooled per cow per period, and stored at $-20^{\circ} \mathrm{C}$ pending milk energy, MUN, and $\mathrm{N}$ analyses. Pooled samples were prepared with correction for differences in milk yield between individual milking events.

Blood Metabolite Variables. Blood samples, extracted from the coccygeal blood vessel, were taken before morning feeding/milking $(0600 \mathrm{~h})$ on d 17 of the experiment (the day before cows entered the respiration chambers) for analysis of glucose, insulin, BHB, and nonesterified fatty acid (NEFA) content in blood.

Milk Microbial Composition. Milk samples were collected on $\mathrm{d} 4$ of the chamber period into sterile tubes at the 0600 and $1600 \mathrm{~h}$ milking to determine the microbial population present. The PathoProof Mastitis PCR assay (Thermo Scientific, Roskilde, Denmark) was performed directly on milk samples to detect the presence of Klebsiella spp., Serratia marcescens, Arcanobacterium pyogenes and Peptoniphilus indolicus, and yeast. A cycle threshold $(\mathbf{C t})$ value of 40 indicates that the microbe was not detectable. Values of 36 to 39 correspond to a quantity of approximately 10 pathogens $/ \mathrm{mL}$ of milk ( $1 \mathrm{log} / \mathrm{mL}$ of milk), and values of 32 to 35 correspond to approximately 100 pathogens $/ \mathrm{mL}$ of milk (2 $\mathrm{log} / \mathrm{mL}$ of milk).

\section{Microbial Counts in Silage}

Total counts of yeast and mold (cfu/g) were determined by spread plating diluted samples on YGC agar plates and counting colonies after a 5 -d incubation at $25^{\circ} \mathrm{C}$ and $37^{\circ} \mathrm{C}$ for yeast and mold, respectively.

\section{Chemical Analysis}

All feed, orts, total excreta, and feces samples were oven-dried at $60^{\circ} \mathrm{C}$ and ground to pass a $1-\mathrm{mm}$ sieve (Peppink 100 AN, Peppink, Olst, the Netherlands) before analyses. Subsamples were analyzed by wet chemistry according to the methods described in detail by Abrahamse et al. (2008). Grass and concentrate samples were analyzed in duplicate for DM, ash, N, crude fat, starch (concentrate only), reducing sugars (all carbohydrates with reducing properties and soluble in $40 \%$ ethanol), NDF, ADF, ADL, and gross energy (GE). Orts were analyzed for DM and ash. Total excreta samples were analyzed for DM, ash, fat, NDF, and GE. Dry matter content of samples were determined by drying at $103^{\circ} \mathrm{C}$ (ISO 6496; ISO-IDF, 1999b) and ash content by combustion at $550^{\circ} \mathrm{C}$ (ISO 5984 ; ISO-IDF, 2002a). Sample GE content was determined by bomb calorimetry (IKA-C700, Janke \& Kunkel, Heitersheim, Germany) according to ISO 9831 (ISO-IDF, 1998). The Berntrop-method (ISO 6492; ISO-IDF, 1999a) was used to determine crude fat, and $\mathrm{N}$ was determined according to the Kjeldahl method with $\mathrm{CuSO}_{4}$ as the catalyst (ISO 5983-2; ISO-IDF, 2009). The NDF content of samples were determined according to a modification of Van Soest et al. (1991), with additional incubations in $\alpha$-amylase and protease as described by Goelema et al. (1998). Reducing sugar analysis was carried out as described by Van Vuuren et al. (1993) using a 40\% ethanol solution. Modifications to this method were as follows: (1) after hydrolysis, $0.25 M \mathrm{~K}_{4} \mathrm{Fe}(\mathrm{CN}) \cdot 63 \mathrm{H}_{2} \mathrm{O}$ (Carrez I) and $0.5 M \mathrm{Zn}\left(\mathrm{C}_{2} \mathrm{H}_{3} \mathrm{O}_{2}\right) \cdot 22 \mathrm{H}_{2} \mathrm{O}$ (Carrez II) were used to clarify the solution, which was a filtered $\left(595^{1} / 2,150-\mathrm{mm}\right.$ diameter 2) dilution dependent on estimated concentrations of sugars, which were dissolved in 10-fold lower concentrations of $\mathrm{CuSO}_{4} \cdot 5 \mathrm{H}_{2} \mathrm{O}$, $\mathrm{Na}_{2} \mathrm{CO}_{3} \cdot 10 \mathrm{H}_{2} \mathrm{O}$, and neocuproine; (2) concentrations were measured using a spectrophotometer (model Du 530, Beckman Coulter, Fullerton, CA) at $460 \mathrm{~nm}$; and (3) concentrations were estimated by calibration using a standard curve ranging from 10 to $100 \mathrm{mg}$ of glucose/L. Starch content of samples were determined enzymatically with dimethyl sulfoxide solubilization according to ISO 15914 (ISO-IDF, 2004b).

Silage and milk samples were further analyzed for FA composition. For FA analysis in silage, samples were extracted with chloroform/methanol (2:1, vol/ 
vol) containing tridecanoic acid (C13:0) as the internal standard, as described by Khan et al. (2009). Fatty acids were methylated by a 2 -step procedure. The first methylation step (basic) was performed by adding $3 \mathrm{~mL}$ $0.5 \mathrm{~N} \mathrm{NaOH}$ and heating for $30 \mathrm{~min}$ at $50^{\circ} \mathrm{C}$. For the second methylation step (acid), $2 \mathrm{~mL} \mathrm{HCl} /$ methanol $(1: 1, \mathrm{vol} / \mathrm{vol})$ was added and heated for $10 \mathrm{~min}$ at $50^{\circ} \mathrm{C}$. After cooling, $2 \mathrm{~mL}$ of hexane and $2 \mathrm{~mL}$ of distilled water were added to the mixtures, which were then mixed and centrifuged at $800 \mathrm{~g}$ for $5 \mathrm{~min}$ at $20^{\circ} \mathrm{C}$. The hexane layer was removed, and another $2 \mathrm{~mL}$ of hexane was added to the aqueous layer, which was mixed and then centrifuged at $800 \times g$ for $5 \mathrm{~min}$ at $20^{\circ} \mathrm{C}$. Both hexane fractions were combined and evaporated to dryness under an $\mathrm{N}_{2}$ flux and resolve in $1 \mathrm{~mL}$ of hexane. Methyl fatty acids were separated and detected by GCflame ionization detector and quantified by the internal standard procedure as described by Khan et al. (2009). Milk fat was extracted from the milk samples and fatty acid methyl esters were prepared from fat fractions (ISO 15884; ISO-IDF, 2002b). Methyl esters were analyzed (ISO 15885; ISO-IDF, 2002c) on a TRACE Ultra gas chromatograph (Thermo Electron Corporation, Waltham, MA) with a split/splitless injector operated in split mode (split ratio 1:100), at a temperature of $270^{\circ} \mathrm{C}$, using a Varian WCOT fused silica column with CP-select $258 \mathrm{CB}$ for fatty acid methyl esters as stationary phase $(100 \mathrm{~m} \times 0.25 \mathrm{~mm}$ i.d.; Varian Inc., Palo Alto, CA) and hydrogen as carrier gas, and fitted to a flame ionization detector $\left(250^{\circ} \mathrm{C}\right)$. The initial temperature was held at $65^{\circ} \mathrm{C}$ for $1 \mathrm{~min}$, increased to $225^{\circ} \mathrm{C}$ at $3^{\circ} \mathrm{C} / \mathrm{min}$, and held at $225^{\circ} \mathrm{C}$ for $5 \mathrm{~min}$. A volume of 1 $\mu \mathrm{L}$ was injected. Peaks were identified and quantified using pure methyl esters (Sigma-Aldrich, Zwijndrecht, the Netherlands; Larodan, Malmo, Sweden; Lipidox).

Milk composition was analyzed by mid-infrared reflection spectroscopy at VVB Milk Control Station (Nunspeet, the Netherlands) using standard procedures (ISO 9622; ISO-IDF, 1999c) for GE and N content as described previously and for urea content based on the enzymatic method using difference in $\mathrm{pH}$ (ISO 14637; ISO-IDF, 2004).

From the CRC unit, samples of condensed water (i.e., collected from the heat exchanger) and air (i.e., through which the outflowing air was led, to trap aerial ammonia) were analyzed for $\mathrm{N}$, in a $25 \%$ sulfuric acid solution (wt/wt) of each.

\section{Statistical Analysis}

For statistical analysis, treatments were blocked as long term (yes/no) and short term (yes/no), so that long-term, short-term, and interaction effects could be analyzed. Data were analyzed using PROC MIXED of SAS (SAS 9.3; SAS Institute, 2011). The statistical model included the fixed effects of treatment (divided into long term and short term), period, and block, and cow (block) was treated as a random effect. Nonsignificant interaction terms were removed from the model. The fixed effect of chamber was not significant and thus not included. All results reported are least squares means, and significant effects were declared when $P \leq$ 0.05 , and tendencies when $0.05 \leq P \leq 0.10$.

\section{RESULTS}

\section{Silage and Diet Composition}

Chemical composition of the experimental silages and grain are summarized in Tables 1 and 2 . The treatment silage was slightly lower in $\mathrm{CP}$ and reducing sugars, and similar in NDF and ADF, compared to the control silage (Table 1). The silage $\mathrm{pH}, \mathrm{LA}$, acetic acid, and ammonia content of control and treated silages were similar (Table 1). The FA composition of silages, as reported in Table 2, was largely similar between control and treated silages.

Chemical composition of the experimental diets is summarized in Table 3. Diets with long-term inoculants $(\mathrm{GS}+\mathrm{L}$ and $\mathrm{GS}+\mathrm{S}+\mathrm{L})$ were slightly lower in $\mathrm{CP}$ and reducing sugars and slightly greater in starch compared to the control diets (GS and GS+S), but short-term inoculated diets $(\mathrm{GS}+\mathrm{S}$ and $\mathrm{GS}+\mathrm{S}+\mathrm{L})$ did not differ greatly from the control diets (GS and GS+L).

\section{Intake, Milk Yield, Milk Composition, and Methane Emissions}

Dry matter intake and BW were not affected by long-term or short-term silage inoculation (Table 4). Milk yield $(\mathrm{kg} / \mathrm{d})$ and fat- and protein-corrected milk yield (FPCM; kg/d) were not affected by short-term silage inoculation in this study. However, milk yield tended $(P=0.083)$ to be greater with long-term silage inoculation. Similarly, milk CP, lactose, and fat $(\mathrm{kg} / \mathrm{d}$ and \%) did not significantly differ from control values with long- or short-term inoculations. However, a trend was seen for greater milk lactose yield $(\mathrm{kg} / \mathrm{d})(P=$ 0.066 ) with long-term inoculation that coincided with the trend for greater milk yield.

Milk urea was significantly lower with the long-term inoculation $(P=0.027$; Table 4$)$, coinciding with lower dietary CP content (Table 3). The efficiency of milk $\mathrm{N}$ production ( $\mathrm{N}$ milk, \% $\mathrm{N}$ intake) was not affected (Table 5).

Several of the long-chain FA in milk differed with long- and short-term inoculations (Table 6). A trend existed for the UFA content of milk to be lower with 
Table 1. Chemical composition ( $\mathrm{g} / \mathrm{kg}$ of DM unless otherwise noted) of grass silages and concentrate

\begin{tabular}{lccc}
\hline & \multicolumn{2}{c}{ Experimental grass silage } & \\
\cline { 2 - 3 } Item & Control & Treated & Concentrate \\
\hline Chemical composition & & & \\
DM, g/kg & 463 & 461 & 910 \\
OM & 900 & 901 & 902 \\
CP & 174 & 167 & 245 \\
NDF & 476 & 478 & 158 \\
ADF & 283 & 288 & 103 \\
ADL & 21 & 20 & 26 \\
Reducing sugars & 61 & 55 & 100 \\
Starch & - & 42 & 231 \\
Fat & 18.9 & 18.8 & 25 \\
Gross energy, MJ/kg of DM & & & 17.5 \\
Ensiling characteristics & 4.7 & 4.8 & - \\
pH & 45 & 40 & - \\
Lactic acid & 13 & 13 & - \\
Acetic acid & 2.8 & 2.7 & - \\
Ammonia & & & \\
\hline
\end{tabular}

long-term silage inoculation $(P=0.080)$, and the PUFA content was significantly lower $(P=0.007)$. The C18:1 trans-11 FA content in milk was lower $(P=$ $0.008)$ with long-term inoculation, suggesting that the last step of biohydrogenation (C18:1 trans-11 to C18:0) was more efficient in the digestive tract. Similarly, C18:3 cis-9,12,15 and C18:0 were also lower with the long-term inoculation. These changes occurred despite minimal differences in silage FA composition (Table 2), suggesting that differences are due to changes in rumen digestion and fermentation.

Methane emission expressed in units of grams per day, grams per kilogram of DMI, grams per kilogram of milk yield, or grams per kilogram of FPCM was not af-

Table 2. Long-chain fatty acid (FA) composition of control and inoculant-treated grass silages

\begin{tabular}{lcc}
\hline & \multicolumn{2}{c}{ Grass silage } \\
\cline { 2 - 3 } Silage fatty acid, & Control & Treated \\
g/kg of DM & & \\
\hline Individual FA & 0.12 & 0.13 \\
C14:0 & 0.59 & 0.55 \\
C14:0 anteiso & 3.83 & 3.52 \\
C16:0 & 0.75 & 0.72 \\
C16:0 anteiso & 0.10 & 0.06 \\
C16:1 & 0.38 & 0.30 \\
C18:0 & 0.60 & 0.52 \\
C18:1 cis-9 & 0.10 & 0.08 \\
C18:1 cis-11 & 3.12 & 3.06 \\
C18:2 cis-9,12 & 0.10 & 0.07 \\
C18:2 trans-10,cis-12 & 8.48 & 8.76 \\
C18:3 cis-9,12,15 & & \\
Summary & 18.90 & 18.32 \\
Total FA & 6.24 & 5.67 \\
SFA & 12.66 & 12.65 \\
UFA & 0.80 & 0.65 \\
MUFA & 11.86 & 11.99 \\
PUFA & & \\
\hline
\end{tabular}

fected by long- or short-term silage inoculation (Table $4)$.

\section{Diet Digestibility, N Balance, and Energy Balance}

Dietary NDF and fat digestibility was not affected by long-term or short-term LAB inoculation (Table 5). Similarly, treatments had no effects on $\mathrm{N}$ balance or energy balance. However, within the energy balance analysis, a trend $(P=0.062)$ existed for $\mathrm{CH}_{4}$ production $\left(\mathrm{kJ} / \mathrm{kg}\right.$ of $\mathrm{BW}^{0.75}$ per day) to be greater with the long-term inoculation as well as for heat production $\left(\mathrm{kJ} / \mathrm{kg}\right.$ of $\mathrm{BW}^{0.75}$ per day), coinciding with the numerically greater GE intake (kJ/kg of $\mathrm{BW}^{0.75}$ per day).

\section{Blood Metabolites}

The blood metabolites glucose, NEFA, BHB, and insulin were not affected by long- or short-term silage inoculation (Table 7).

\section{Milk Microbial Analysis}

Results of Ct analysis, indicating the presence of microorganisms in milk, are presented in Table 8. Klebsiella spp. analysis had only 2 values different from 40 and yeast $\mathrm{Ct}$ data had no deviations from 40 , indicating undetectable quantities; therefore, no statistical analysis was warranted for these microbes. For Serratia marcescens and for Arcanobacterium pyogenes and Peptoniphilus indolicus or both, neither long-term nor short-term treatment had a significant effect on Ct values obtained for these microbes (Table 8). All treatment means had $\mathrm{Ct}$ values greater than 35 , indicating low presence in milk. Total pathogen load (the sum of 
Table 3. Chemical composition, gross energy value, and forage-to-concentrate ratio of treatment diets

\begin{tabular}{lcccc}
\hline & \multicolumn{4}{c}{ Treatment diet $^{1}$} \\
\cline { 2 - 5 } Variable & GS & GS+S & GS+L & GS+S+L \\
\hline Chemical composition, g/kg of DM & 900 & 900 & 901 & 901 \\
OM & 192 & 192 & 187 & 187 \\
CP & 396 & 398 & 395 & 394 \\
NDF & 238 & 239 & 240 & 239 \\
ADF & 22 & 22 & 22 & 22 \\
ADL & 71 & 71 & 66 & 67 \\
Reducing sugars & 58 & 57 & 60 & 61 \\
Starch & 39 & 39 & 38 & 38 \\
Fat & 18.5 & 18.5 & 18.4 & 18.4 \\
Gross energy, MJ/kg of DM & 0.75 & 0.76 & 0.74 & 0.74 \\
Forage:concentrate & &
\end{tabular}

${ }^{1} \mathrm{GS}=$ grass silage (mainly ryegrass) with no inoculant; GS+S = grass silage with a short-term inoculant (applied $16 \mathrm{~h}$ before feeding); GS $+\mathrm{L}=$ grass silage with a long-term inoculant (applied at harvest); GS $+\mathrm{S}+\mathrm{L}=$ grass silage with both long- and short-term inoculants.

Ct values for Klebsiella spp., Serratia marcescens, and Arcanobacterium pyogenes and Peptoniphilus indolicus or both and yeast) was also not significantly affected by treatment (Table 8). Milk SCC did not differ with longor short-term silage inoculation either (Table 4) but was numerically lower with the short-term inoculation.

\section{DISCUSSION}

\section{DMI, Diet Digestibility, and Milk Yield}

In the current study, no significant effect of LAB inoculation was observed on DMI. Dry matter intake responses reported in the literature to LAB silage inoculations are variable. Some studies show increases in DMI with inoculated corn (Kung et al., 1993; Basso et al., 2014) and grass silages (Gordon, 1989; Mayne, 1990; Petit and Flipot, 1990; Meeske et al., 1999), but others have shown no effect with corn silage (Wardynski et al., 1993; Fellner et al., 2001), grass silage (Keady et al., 1994; Keady and Murphy, 1996), or barley silage (McAllister et al., 1995). In the studies in which positive responses in DMI were observed, they were often attributed to improved NDF digestibility or more favorable fermentation conditions such as $\mathrm{pH}$, but not always (Bayatkouhsar et al., 2011). In agreement with

Table 4. Dry matter intake, BW, milk yield, milk composition, and methane emissions from cows fed diets with or without long-term and shortterm silage inoculation with lactic acid bacteria

\begin{tabular}{|c|c|c|c|c|c|c|c|c|}
\hline \multirow[b]{2}{*}{ Variable } & \multicolumn{4}{|c|}{ Treatment $\operatorname{diet}^{1}$} & \multirow[b]{2}{*}{ SEM } & \multicolumn{3}{|c|}{$P$-value } \\
\hline & GS & $\mathrm{GS}+\mathrm{S}$ & $\mathrm{GS}+\mathrm{L}$ & $\mathrm{GS}+\mathrm{S}+\mathrm{L}$ & & Long-term & Short-term & $\begin{array}{l}\text { Long-term } \\
\times \text { short-term }\end{array}$ \\
\hline DMI, $\mathrm{kg} / \mathrm{d}$ & 15.9 & 16.4 & 16.4 & 16.4 & 0.88 & 0.402 & 0.401 & 0.495 \\
\hline $\mathrm{BW}, \mathrm{kg}$ & 584 & 586 & 590 & 585 & 13.8 & 0.403 & 0.707 & 0.322 \\
\hline Milk yield, kg/d & 22.1 & 22.2 & 22.6 & 22.9 & 0.77 & 0.083 & 0.544 & 0.845 \\
\hline $\mathrm{FPCM}^{2}, \mathrm{~kg} / \mathrm{d}$ & 22.5 & 22.7 & 23.3 & 23.2 & 0.76 & 0.143 & 0.908 & 0.749 \\
\hline Milk lactose, $\mathrm{kg} / \mathrm{d}$ & 1.00 & 1.00 & 1.02 & 1.04 & 0.033 & 0.066 & 0.644 & 0.487 \\
\hline Milk lactose, $\%$ & 4.55 & 4.51 & 4.53 & 4.57 & 0.04 & 0.213 & 0.916 & 0.024 \\
\hline Milk fat, kg/d & 0.95 & 0.96 & 0.99 & 0.97 & 0.036 & 0.389 & 0.793 & 0.714 \\
\hline Milk fat, $\%$ & 4.31 & 4.31 & 4.33 & 4.27 & 0.137 & 0.932 & 0.855 & 0.825 \\
\hline Milk urea, mg/dL & 29.6 & 29.4 & 27.0 & 26.2 & 2.53 & 0.027 & 0.625 & 0.801 \\
\hline Milk SCC SCl $^{3}$ & 139 & 126 & 158 & 104 & 70.7 & 0.954 & 0.280 & 0.508 \\
\hline $\mathrm{CH}_{4}, \mathrm{~g} / \mathrm{d}$ & 352 & 353 & 359 & 366 & 18.3 & 0.120 & 0.526 & 0.599 \\
\hline
\end{tabular}

${ }^{1} \mathrm{GS}=$ grass silage (mainly ryegrass) with no inoculant; GS+S = grass silage with a short-term inoculant (applied $16 \mathrm{~h}$ before feeding); GS+L $=$ grass silage with a long-term inoculant (applied at harvest); GS $+\mathrm{S}+\mathrm{L}=$ grass silage with both long- and short-term inoculants.

${ }^{2} \mathrm{FPCM}=$ fat- and protein-corrected milk yield.

${ }^{3}$ Cells $\times 1,000 / \mathrm{mL}$. 
Table 5. Digestibility, N, and energy balance from cows fed diets with or without long-term and short-term silage inoculation with lactic acid bacteria

\begin{tabular}{|c|c|c|c|c|c|c|c|c|}
\hline Variable & \multicolumn{4}{|c|}{ Treatment $\operatorname{diet}^{1}$} & SEM & \multicolumn{3}{|c|}{$P$-value } \\
\hline Fat digestibility $\%$ & 39.5 & 42.4 & 40.4 & 38.7 & 1.95 & 0.483 & 0.742 & 0.244 \\
\hline \multicolumn{9}{|l|}{$\mathrm{N}$ balance } \\
\hline $\mathrm{N}$ intake, $\mathrm{mg} / \mathrm{kg}$ of $\mathrm{BW}^{0.75}$ per day & 4,129 & 4,235 & 4,155 & 4,085 & 212 & 0.829 & 0.277 & 0.525 \\
\hline $\mathrm{N}$ milk, $\mathrm{mg} / \mathrm{kg}$ of $\mathrm{BW}^{0.75}$ per day & 883 & 909 & 944 & 870 & 45.0 & 0.725 & 0.183 & 0.048 \\
\hline $\mathrm{N}$ milk, $\%$ of $\mathrm{N}$ intake & 21.4 & 21.7 & 22.4 & 21.6 & 0.87 & 0.453 & 0.757 & 0.504 \\
\hline $\mathrm{N}$ retained, ${ }^{2} \mathrm{mg} / \mathrm{kg}$ of $\mathrm{BW}^{0.75}$ per day & 399 & 496 & 433 & 414 & 68.5 & 0.670 & 0.497 & 0.323 \\
\hline $\mathrm{N}$ retained, $\%$ of $\mathrm{N}$ intake & 9.5 & 11.8 & 10.1 & 10.0 & 1.44 & 0.658 & 0.428 & 0.391 \\
\hline $\mathrm{N}$ condensate + acid, $\%$ of $\mathrm{N}$ intake ${ }^{3}$ & 1.9 & 1.4 & 1.4 & 1.2 & 0.22 & 0.202 & 0.252 & 0.601 \\
\hline \multicolumn{9}{|l|}{ Energy balance } \\
\hline GE intake, ${ }^{4} \mathrm{~kJ} / \mathrm{kg}$ of $\mathrm{BW}^{0.75}$ per day & 2,480 & 2,537 & 2,517 & 2,544 & 130.7 & 0.661 & 0.409 & 0.771 \\
\hline Energy in milk, $\%$ of GE & 23.8 & 23.3 & 24.3 & 23.6 & 1.15 & 0.433 & 0.667 & 0.838 \\
\hline Heat production, $\mathrm{kJ} / \mathrm{kg}$ of $\mathrm{BW}^{0.75}$ per day & 869 & 859 & 875 & 889 & 26.5 & 0.051 & 0.877 & 0.139 \\
\hline Heat production, $\%$ of GE intake & 35.2 & 34.3 & 35.2 & 35.3 & 1.01 & 0.264 & 0.356 & 0.293 \\
\hline \multicolumn{9}{|l|}{ Energy retained, $\mathrm{kJ} / \mathrm{kg}$ of $\mathrm{BW}^{0.75}$ per day } \\
\hline Total $^{6}$ & -14 & 51 & 58 & 53 & 36.6 & 0.154 & 0.236 & 0.174 \\
\hline Protein $^{7}$ & 59 & 73 & 64 & 61 & 10.1 & 0.670 & 0.497 & 0.323 \\
\hline Fat $^{8}$ & -74 & -22 & -5 & -8 & 33.1 & 0.123 & 0.337 & 0.283 \\
\hline
\end{tabular}

${ }^{1} \mathrm{GS}=$ grass silage (mainly ryegrass) with no inoculant; GS+S = grass silage with a short-term inoculant (applied $16 \mathrm{~h}$ before feeding); GS+L $=$ grass silage with a long-term inoculant (applied at harvest); GS+S+L = grass silage with both long- and short-term inoculants.

${ }^{2} \mathrm{~N}$ retained $=\mathrm{N}$ intake $-\mathrm{N}$ in manure $-\mathrm{N}$ in milk $-\mathrm{N}$ in condensate collected from heat exchanger $-\mathrm{N}$ trapped from the outflowing air.

${ }^{3} \mathrm{~N}$ in condensate collected from heat exchanger plus $\mathrm{N}$ trapped in outgoing air.

${ }^{4} \mathrm{GE}=$ gross energy.

${ }^{5} \mathrm{ME}$ intake $=\mathrm{GE}$ intake - energy in excreta - energy in $\mathrm{CH}_{4}$.

${ }^{6}$ Energy retention total $=\mathrm{ME}$ intake - heat production - energy in milk.

${ }^{7}$ Energy retention protein $=(\mathrm{N}$ retained $/ 1,000) \times 6.25 \times 23.6 \mathrm{~kJ} / \mathrm{g}$.

${ }^{8}$ Energy retention fat $=$ energy retention total - energy retention protein.

a lack of effect on DMI in the present study, no significant effect was observed here on NDF digestibility either. The long-term inoculant and grass silage used in the present study were the same as the grass silage (bales) and LM1 inoculant mixture used in Ellis et al. (2016) (experiment 3). In that in vitro study, LM1 significantly increased OM digestibility, as measured by OM disappearance during $72 \mathrm{~h}$. Unfortunately, OM digestibility could not be reported in the current study because of total mixing of the urine and feces in the CRC, but no other results suggested such an OM digestibility increase occurred in vivo either (lack of effects on NDF digestibility, fat digestibility, DMI, and milk yield). Many differences likely exist between the in vitro and in vivo environment, including retention time. Within the rumen, degradation and passage of nutrients are occurring simultaneously. Because fractional passage rates vary between 0.02 and $0.05 / \mathrm{h}$ for grass and corn silage (Warner et al., 2014), retention times are well below the 72-h endpoint used with in vitro studies. The longer incubation time in vitro may explain the significant effects, but observed effects on digestibility in vivo are lacking.

In the literature, increases in milk yield with silage inoculations are generally attributed to increases in ME intake, either due to increased DMI (Gordon, 1989; Mayne, 1990; Kung et al., 1993) or improved DM digestibility (Martinsson, 1992). However, in many studies changes in milk yield did not occur (Keady and Murphy, 1996, 1997; Kristensen et al., 2010) or were at nonsignificant levels (Bayatkouhsar et al., 2011). The results of the present study (nonsignificant effect on DMI, trend for greater milk yield) therefore fall within the range of results presented in the literature. Bayatkouhsar et al. (2011), for example, reported a significant increase in DMI with a numerical increase in milk yield 
Table 6. Milk fatty acid (FA) composition ( $\mathrm{g} / 100 \mathrm{~g}$ of FA) from cows fed diets with or without long-term and short-term silage inoculation with lactic acid bacteria

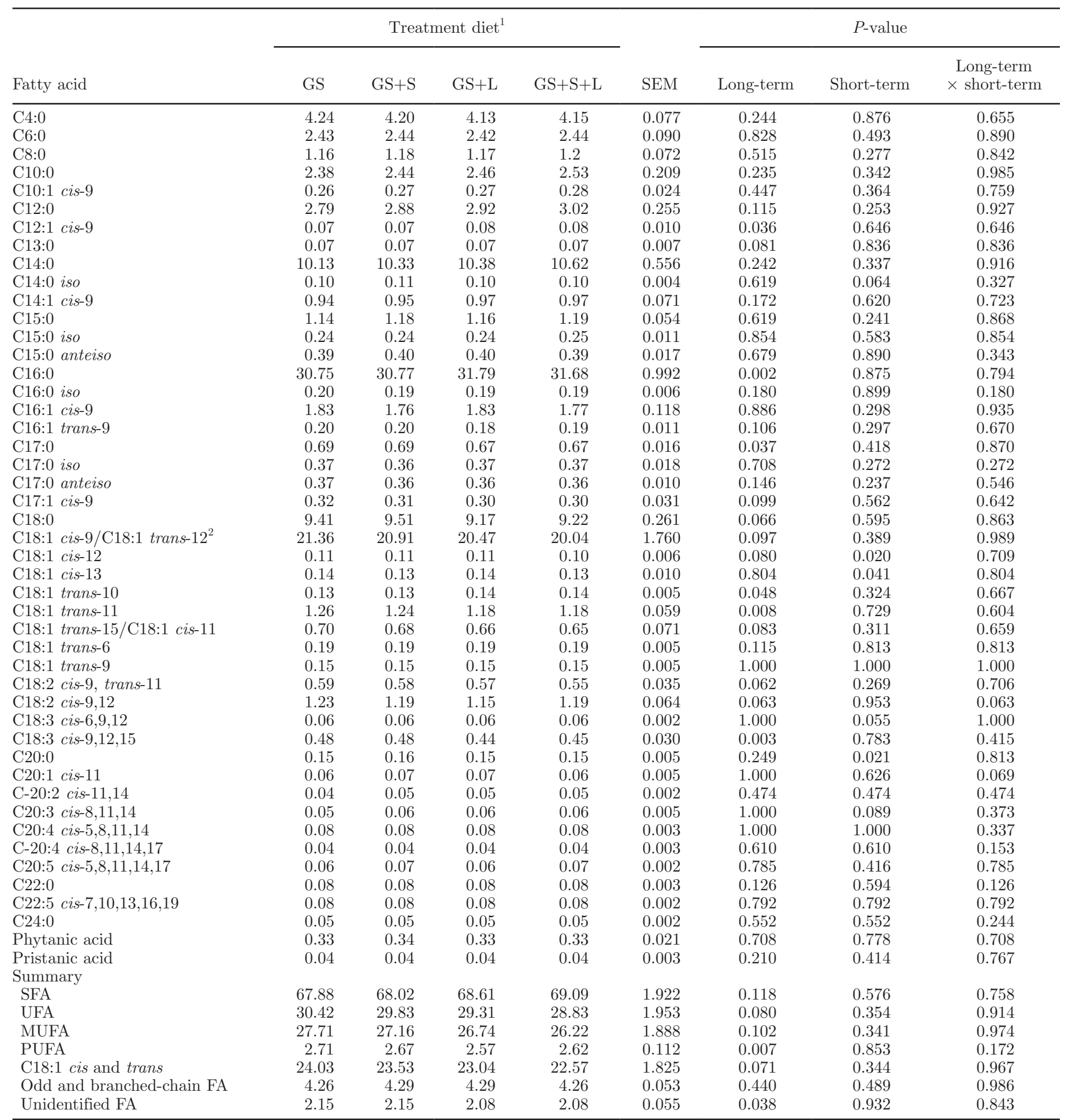

${ }^{1} \mathrm{GS}=$ grass silage (mainly ryegrass) with no inoculant; GS+S = grass silage with a short-term inoculant (applied $16 \mathrm{~h}$ before feeding); GS+L $=$ grass silage with a long-term inoculant (applied at harvest); GS $+\mathrm{S}+\mathrm{L}=$ grass silage with both long- and short-term inoculants.

${ }^{2} \mathrm{C} 18: 1$ cis-9 represents the sum of C18:1 cis-9 and C18:1 trans-12 because these 2 FA could not be separated in analysis. The portion of C18:1 trans-12 is considered negligible because it is always present in small quantities. 
Table 7. Blood metabolite results from cows fed diets with or without long-term and short-term silage inoculation with lactic acid bacteria

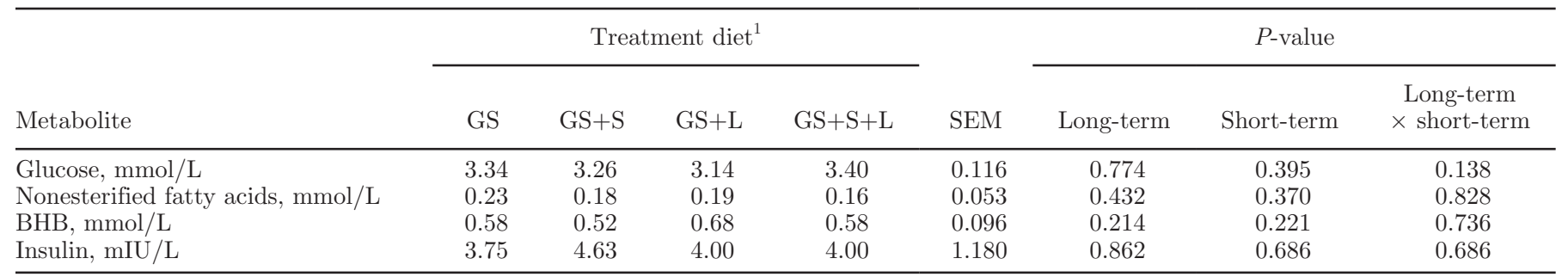

${ }^{1} \mathrm{GS}=$ grass silage (mainly ryegrass) with no inoculant; GS+S = grass silage with a short-term inoculant (applied $16 \mathrm{~h}$ before feeding); GS+L $=$ grass silage with a long-term inoculant (applied at harvest); GS $+\mathrm{S}+\mathrm{L}=$ grass silage with both long- and short-term inoculants.

with a commercial or laboratory-grown LAB inoculant applied on corn silage, but no treatment effect on composition of the silages, digestibility, ruminal $\mathrm{pH}$, ruminal ammonia concentration, blood plasma metabolites, or milk composition were observed. Some of the differences observed in the literature may be attributable to the type of silage used. Although it is not pertinent to explaining the results of the present study, Ellis et al. (2016) observed in vitro an effect of LAB on the fermentation of grass or grass-clover silages, but not on fermentation of corn silage. This difference is likely due to LAB substrate preferences and the difference in silage chemical composition (mainly starch and sugar content) between grass and corn silage.

In the present study, the long-term LAB inoculant had significant effects on milk FA composition, but results contrast with those of Maragkoudakis et al. (2010), who found a significant increase in PUFA with a $12 \log \mathrm{cfu} / \mathrm{d}$ treatment of $L b$. plantarum to goats fed diets based on oat hay and barley straw. Maragkoudakis et al. (2010) also saw significant increases in C18:2 cis-9,12, C18:3 cis-9,12,15, and C18:2 cis-9,trans-11, whereas these FA were decreased in the present study with long-term LAB inoculation $(P=0.063,0.003$, and 0.062 , respectively), suggesting an increase in ruminal biohydrogenation. Rumen biohydrogenation is affected by various factors, including the amount of UFA and the amount of fiber in the diet (Harfoot and Hazlewood, 1997). The SFA and UFA contents of the control and treated grass silages were similar, however (Table 2), and NDF and fat digestibilities were also similar (Table 5).

Fibrolytic bacteria may be the main biohydrogenators in the rumen (Boeckaert et al., 2008), which would explain the correlation between biohydrogenation level and the fiber content of the diet. Diets low in fiber generally appear to result in rumen biohydrogenation of UFA that is reduced, incomplete, or both, and high fiber levels are associated with high levels of biohydrogenation in the rumen. Far less seems to be known about the effect of the type of fiber on biohydrogenation. A possible hypothesis is that high degradability of fiber coincides with high activity of fibrolytic microbes and consequently with high biohydrogenation activity. Li and Meng (2006) evaluated the effect of different sources of fiber (wheat straw, soybean hulls, purified cellulose) on biohydrogenation of unsaturated fatty acids in vitro. The more lignified, slowly degradable fiber of wheat straw was associated with reduced biohydrogenation levels of unsaturated C18 FA compared with the more rapidly degradable fiber of soybean hulls or the purified source. These results indicate that next to the level of fiber, the type of fiber also affects rumen biohydrogenation.

Table 8. Milk microbial analysis (cycle threshold values) from cows fed diets with or without long-term and short-term silage inoculation with lactic acid bacteria

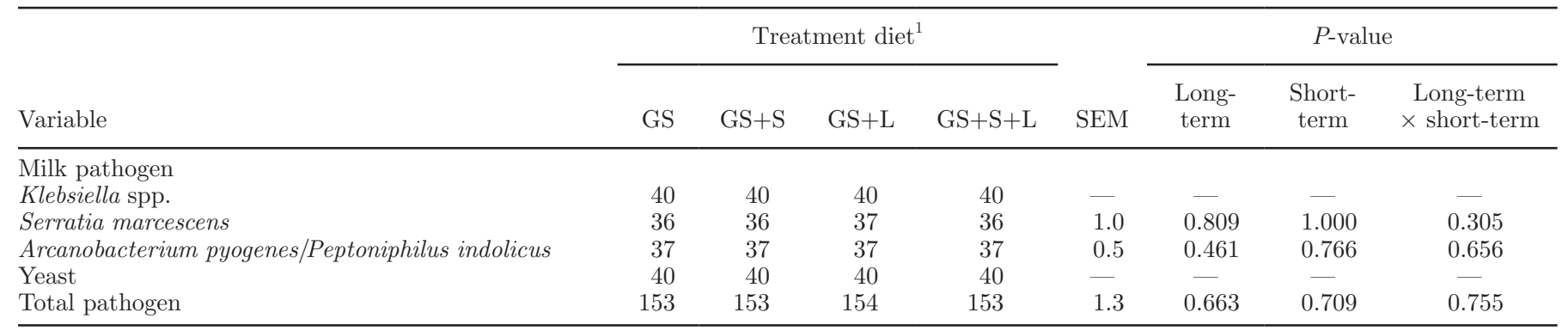

${ }^{1} \mathrm{GS}=$ grass silage (mainly ryegrass) with no inoculant; GS+S = grass silage with a short-term inoculant (applied $16 \mathrm{~h}$ before feeding); GS+L $=$ grass silage with a long-term inoculant (applied at harvest); GS+S+L = grass silage with both long- and short-term inoculants. 
The milk FA profile has been suggested to be a proxy of $\mathrm{CH}_{4}$ production (Chilliard et al., 2009). Although the significantly increased level of C16:0 and decreased level of C18:1 trans-10 plus C18:1 trans-11 in milk fat with long-term LAB inoculation would suggest increased $\mathrm{CH}_{4}$ production $(\mathrm{g} / \mathrm{kg}$ of $\mathrm{DM}$ and $\mathrm{g} / \mathrm{kg}$ of $\mathrm{FPCM}$; van Lingen et al., 2014), this pattern was not observed in the present experiment.

\section{Milk Microbial Analysis}

Mastitis usually has an infectious origin through introduction of bacteria via the teat duct. Traditionally Staphylococcus aureus has been the main cause, but Staphylococcus epidermidis is also emerging as a leading cause (Zhang and Maddox, 2000). Soleimani et al. (2010) showed an inhibitory effect of LAB inoculation with $L b$. plantarum, but not of $L b$. acidophilus, $L b$. case $i$, and $L b$. reuteri, on growth of $S$. aureus in vitro and suggested that it might be used to control $S$. aureus with mastitis. Jiménez et al. (2008) examined the effect of orally supplemented Lactobacillus salivarius and Lactobacillus gasseri on staphylococcal mastitis in humans, and found that although mastitis persisted in the control groups, the LAB treatment group showed no clinical signs of mastitis by $\mathrm{d} 14$. Elsewhere, $L b$. gasseri, Lb. fermentum, and Lb. salivarius isolated from milk have shown a probiotic effect in controlling mastitis (Martín et al., 2005).

How orally supplemented LAB may reach the mammary gland has been up for some debate (via a direct pathway or contamination) (Fernández et al., 2013). Either way, it was of interest to examine whether LAB inoculation as used in the present study had any effect on several microbial species associated with mastitis in milk, as well as the milk SCC, a typical indicator of the presence of mastitis. However, of the mastitis pathogens analyzed in milk, Klebsiella spp. and yeast were negligible (Table 8). Serratia marcescens and Arcanobacterium pyogenes/Peptoniphilus indolicus were present in measurable quantities, but their Ct count numbers were low and did not differ between treatments (Table 8). Milk SCC did not differ significantly between treatments either, although it was numerically lower with the short-term LAB inoculation (Table 4).

As expected, milk SCC and microbial Ct values were correlated. Regressions of total pathogen load $(\mathrm{Ct})$ $=155( \pm 1.8)-0.013( \pm 0.0036) \times$ milk SCC $($ cells $\times$ $1,000 / \mathrm{mL}$ ) (slope $P=0.001$ ) and Serratia marcescens $(\mathrm{Ct})=36( \pm 1.6)-0.0092( \pm 0.0032) \times$ milk SCC $($ cells $\times 1,000 / \mathrm{mL}$ ) (slope $P=0.008)$ both produced significant negative slope parameters. Overall, no indication of mastitis inhibition was apparent, but the control treatment cows had minimal presence of mastitis pathogens to start with. Without first inducing mastitis, making conclusions about any inhibitory effect by LAB is difficult, and it therefore remains an interesting potential implication of LAB inoculants.

\section{Methane Emissions}

In the current study, no significant effects of longor short-term LAB inoculation were observed on $\mathrm{CH}_{4}$ emission regardless of the unit of expression (Table 4), except for a trend of increased $\mathrm{CH}_{4}$ produced per unit of metabolic BW ( $P=0.062$; Table 5$)$. This trend appears to be related to a numerically greater energy intake and numerically greater NDF digestibility. This is despite several in vitro studies having suggested that reductions in $\mathrm{CH}_{4}$ emissions are possible because of either changes in $\mathrm{OM}$ digestibility or direct antimicrobial effects of LAB. For example, O'Brien et al. (2013) reported that cumulative $\mathrm{CH}_{4}(\mathrm{~mL} / 24 \mathrm{~h})$ and $\mathrm{CH}_{4} / \mathrm{CO}_{2}(\mathrm{~mol} / \mathrm{mol})$ were reduced with a $L b$. plantarum (TUA1490L) inoculum or a cell-free supernatant during an in vitro incubation. However, total VFA production $(\mathrm{m} M)$ was also significantly reduced, and cumulative $\mathrm{CO}_{2}(\mathrm{~mL} / 24 \mathrm{~h})$ was numerically reduced, indicating a general decline in fermentation. Asa et al. (2010) investigated in vitro fermentation of a kleingrass-concentrate mixture with supernatant from Lc. lactis (ATCC 19435), Lc. lactis (NCIMB702054), Lb. plantarum (TUA1490L), and Leuconostoc citreum (JCM 9698). The Lb. plantarum (TUA1490L) supernatant significantly reduced cumulative $\mathrm{CH}_{4}$ production $(\mathrm{mL})$, but also numerically reduced total VFA concentration $(\mathrm{m} M)$ and total $\mathrm{CO}_{2}$ production $(\mathrm{mL})$. Jalc et al. (2009a) investigated inoculation of grass silage in vitro with E. faecium (CCM 4231), Lactobacillus fermentum, or Lb. plantarum (CCM 4000) and found significant reductions in $\mathrm{CH}_{4}\left(\mathrm{~mol}\right.$ of $\mathrm{CH}_{4} / \mathrm{kg}$ of digested DM) for all LAB. For the E. faecium and $L b$. fermentum inoculations, OM degradability $(\mathrm{g} / \mathrm{kg}$ of DM) was numerically reduced, but for $L b$. plantarum it was significantly increased, which seemed promising. Jalc et al. (2009b) then investigated the same LAB on corn silage in vitro and found significant increases in OM degradability ( $\mathrm{g} / \mathrm{kg}$ of $\mathrm{DM})$ with all $3 \mathrm{LAB}$ inoculations and no significant changes in $\mathrm{CH}_{4}(\mathrm{~mol} / \mathrm{kg}$ of digested DM). In our own previous in vitro study, LM1 from experiment 3 (Ellis et al., 2016), involving the same grass and long-term inoculant as in the present in vivo study, resulted in increased $\mathrm{CH}_{4}(\mathrm{~mL} / \mathrm{g}$ of $\mathrm{OM})$ at early time points (up to $24 \mathrm{~h}$ ) which was associated with an increase in total gas production and $\mathrm{OM}$ digestibility. These in vitro results did not translate into similar responses in the present in vivo experiment, however. 
These results illustrate the strain and substrate specificity of LAB on in vitro fermentation, and they show that similar effects may not be obtained in vivo and in vitro. To our knowledge, no other published work has examined LAB inoculants for their effect on $\mathrm{CH}_{4}$ emissions in vivo. With the variability between strains and substrates, and with some LAB appearing to increase digestibility and others appearing to decrease it or keep it the same, the challenge may be to find the correct LAB for application in vivo. In the present study, because of minimal changes in DMI, digestibility, $\mathrm{CH}_{4}$ and milk yield, such changes did not occur, nor was any direct antimethanogen effect in the rumen (short-term inoculant) indicated.

\section{Lack of Significant Long-Term Inoculum Effects}

The present results indicate minimal responses in animal performance to long-term inoculation of grass silage with LAB. The cause of significant improvements in animal performance observed in some studies, but not others, is still unclear. Strain differences, compounded with differences in basal silages, silage characteristics, and rumen fermentation conditions, are likely responsible for the varying results in the literature.

Based on a power analysis according to the procedure outlined in Kononoff and Hanford (2006), the experimental design and number of animals used in this study should be sensitive enough to detect significant differences (in milk yield, for example) of $\sim 10 \%$ with a probability of 0.969 . Supporting this assumption, others that used the same experimental design and number of animals detected significant effects within the range of 9 to 12\% difference (Martin et al., 2008; Chilliard et al., 2009). Therefore, it does not seem likely that the lack of significant effects observed in the present study was due to an insufficient number of animals, but rather was due to a true lack of treatment effect.

However, several possible reasons exist for the lack of effect of the long-term inoculant treatment observed in the present study that can be examined, related to either failure of inoculated LAB to dominate fermentation or failure to inhibit adverse microbial activity (Weinberg and Muck, 1996). The high DM, high pH, and low LA concentrations of the silages in the present study suggest restricted fermentation and a relatively poor ensiling, which may have contributed to the lack of significant treatment effects. However, the ensiling parameters are fairly typical for the Netherlands where the average for grass silage was $432 \mathrm{~g} / \mathrm{kg}$ of DM, $\mathrm{pH} 5.8, \mathrm{LA} 39 \mathrm{~g} / \mathrm{kg}$ of DM, and acetate $12 \mathrm{~g} / \mathrm{kg}$ of DM in the year of study, 2013 (BLGG AgroXpertus, Oosterbeek, the Netherlands). From Table 1, the average LA:acetate ratio was 3.5 for the control silage and
3.1 for the treated silage, which indicated small differences existed in fermentation end products and that LA as an end product did not dominate fermentation in the treated silage. However, the long-term inoculant also included a L. buchneri strain, a heterofermentative LAB that grows more slowly and produces a greater concentration of acetic acid. Consequently, changes in the LAB population of the silage may not have been overtly reflected in large changes in the LA content or LA:acetate ratio. It is also possible that the inoculant strains did not grow in the grass silage as well as desired or that no results were found because of technical problems related to LAB not being viable at the time of application (e.g., too long storage, heat damage), uneven mixing of the inoculant in the forage, low ambient temperatures, or slow bailing. However, analysis of control and treated silage bales at the time of the trial showed an average total LAB of $6.41( \pm 0.23)$ and 7.02 $( \pm 0.19) \log \mathrm{cfu} / \mathrm{g}$, for the control and treated silage, respectively, indicating that treated silage was indeed greater in LAB content. These values were also greater than the LAB count on fresh grass, prebaling (5.94 \pm $0.03 \log \mathrm{cfu} / \mathrm{g}$ ). This finding supports the premise that the LAB applied were viable and able to grow and ferment during ensiling. It also supports the premise that the eventual LA content, the LA:acetate ratio, or both may not be representative of the LAB mixtures' ability to dominate fermentation or the LAB count in silages. Additionally, if the control silage already has high LAB counts naturally, then the inoculant may not provide any additional benefit, which may explain the lack of treatment effect.

The LAB strains present in the current inoculations were isolated from tomato pulp ( $L b$. buchneri LB1819) and maize silage (Lb. plantarum 6072). Hill (1989) isolated strains of $L b$. plantarum from corn, lucerne, and sorghum and found that when these 3 strains were co-inoculated back onto the crops, the strain originally isolated from a specific crop was found in greater numbers and thus dominated in the silage of that crop. This finding suggests that the best strains for a specific crop would be those obtained from that crop originally. However, characteristics of individual LAB strains can vary considerably and may be beneficial on various other crops. The strains and strain combinations used in the present study were selected because they were commercially available and had been previously shown to have beneficial effects on silage preservation and quality. The $L b$. plantarum strain used is generally known to result in rapid formation of LA, decreasing silage $\mathrm{pH}$ rapidly and preventing development of clostridia, yeasts, fungi, and molds. The Lb. buchneri strain used produces acetic acid and is known to inhibit fungi and help preserve silage upon exposure to air. Previous 
in vitro work (Ellis et al., 2016) showed that inoculants of Lc. lactis, Lb. plantarum, and Lb. buchneri showed the most promise for effects on OM digestibility and $\mathrm{CH}_{4}$ mitigation in grass silage, which indicates potential for in vivo mitigation. A Lc. lactis strain was used in both short- and long-term inoculants. The specific strain used for the long-term inoculant has an oxygenscavenging ability that may play an important role in ensuring a fast establishment of anaerobic conditions in the silage. However, the specific Lc. lactis strain used for the short-term inoculation has been shown to produce nisin, which acts as an antimicrobial and has been shown to reduce $\mathrm{CH}_{4}$ during in vitro studies (Asa et al., 2010).

Failure to inhibit adverse microbial activity may also contribute to a lack of positive treatment effect. Two types of microbial activity can be problematic during silage making, clostridial growth and aerobic microbes. In low DM silages, low WSC content, high buffering capacity, or both may prevent efficient LAB fermentation and thus the development of a sufficiently low $\mathrm{pH}$ to prevent clostridial activity (Hellings et al., 1985; Haigh et al., 1987). The DM content of silages used in this trial were on the high side, however (Table 1), and the reducing sugar content adequate (Table 1), so clostridial activity is unlikely to explain the absence of beneficial effects here. Regarding aerobic stability, some studies have found that homofermentative LAB inoculants actually enhance aerobic deterioration in cereal silages (Weinberg et al., 1993). The explanation given is that high levels of residual WSC, combined with high LA concentrations and lack of inhibitory VFA (such as acetic, propionic, and butyric acids), contributed to aerobic spoilage because WSC are substrates for molds and yeasts and VFA inhibit these organisms (Weinberg et al., 1993). In the present trial, however, the average total yeast count was $3.55( \pm 0.59)$ for control silage and $1.15( \pm 0.84)$ for treated silage $(\log \mathrm{cfu} / \mathrm{g})$, and mold was $1.94( \pm 0.86)$ for control silage and $0.5( \pm 0.5)$ for treated silage $(\log \mathrm{cfu} / \mathrm{g})$. This finding suggests that additional spoilage due to the LAB inoculation was not a problem in the present trial. Indeed, Lb. buchneri, 1 of the 3 microbes used in the long-term LAB inoculant may have preventative effects on aerobic spoilage because it is heterofermentative, produces acetic acid, and also converts LA to acetic acid when oxygen is present (Weinberg and Muck, 1996). With this second mechanism, upon exposure to oxygen approximately one-third of LA will be lost as $\mathrm{CO}_{2}$ on a mass basis. Such a small loss of DM (1-2\%) is much less, however, than the potential loss due to aerobic microbes (Weinberg and Muck, 1996). It seems unlikely that this loss was occurring in the silages used in the present study. Therefore, it seems unlikely that the lack of treatment effect was due to the inability of LAB inoculant to dominate fermentation or to spoilage.

\section{Lack of Significant Short-Term Inoculant Effects}

The LAB have been suggested to have a direct probiotic effect in either silage or the rumen. In a meta-analysis, Muck (1993) noted improvements in fiber digestibility in $30 \%$ of the trials in which it was measured. This result is curious because LAB are not known to have any direct activity on polysaccharides (Weinberg and Muck, 1996). This outcome may have occurred indirectly, however, through an increase in protein availability and digestibility in silage, with the result being beneficial to fibrolytic bacterial growth in the rumen. Alternatively, a probiotic effect has been proposed via the ability of LAB to inhibit pathogens, the ability of some LAB to produce a variety of antimicrobial substances such as bacteriocins, or both (Vandenbergh, 1993; Muller et al., 1996). These compounds may inhibit detrimental microbes in the silage or a particular group of microbes in the rumen. Typically, LAB are not prevalent within the rumen of fresh forage-fed animals, and so their inoculation into the rumen via silage represents a somewhat novel scenario to the rumen with that substrate. The LAB become more prevalent in the rumen when large amounts of sugar or starch are fed (Van Soest, 1994) because of their affinity for these substrates and tolerance for low rumen $\mathrm{pH}$. Weinberg et al. (2003) found that addition of glucose with LAB markedly enhanced the survival of inoculated LAB in rumen fluid, confirming that the LAB strains could compete effectively with the ruminal microflora for exogenous glucose, although some strains grew better than others. Although plenty of substrate exists in the concentrate-fed rumen for rapid LAB growth, a proportion of the dietary WSC has already been metabolized by silage microbes in the rumen of silage-fed animals, meaning that silage-fed animals consume less WSC and the LAB present in the rumen may grow less rapidly because of low substrate availability. In our previous in vitro study (Ellis et al., 2016), 10 LAB strains were added directly to the in vitro medium in 2 experiments to examine their probiotic effects on $\mathrm{OM}$ digestibility, cumulative gas, and $\mathrm{CH}_{4}$ production. Addition of one strain resulted in a significant increase in $\mathrm{OM}$ digestibility (Lb. plantarum), and the gas or $\mathrm{CH}_{4}$ production was not affected by any strain. This finding suggests that LAB potentially have a direct probiotic effect, but strain specificity certainly exists and the mode of action also needs to be determined. The $L c$. lactis strain used in the short-term inoculant in the present study has been shown to produce nisin, a substance with antimicrobial activity that has been shown 
to inhibit $\mathrm{CH}_{4}$ production in vitro (Asa et al., 2010). However, in the current study, no effect of the shortterm inoculant was found on any response variable, and others have also reported mixed results. Keady and Steen (1996) found that a short-term inoculation of grass silage with $L b$. plantarum did not significantly affect DMI, total-tract digestibility, or degradability or fermentation in the rumen, and they found no evidence of a "direct" effect of the LAB in the rumen. However, in a previous study by the same authors, a long-term inoculation with $L b$. plantarum MTD1 was associated with significant increases in DM, OM, N, and NDF digestibility coefficients with inoculated silages (Keady and Steen, 1995). Khuntia and Chaudhary (2002) also found that a short-term inoculation with a mixed culture of LAB increased DMI, live weight gain, and DM digestibility in calves. It appears this area could benefit from further research, to determine if and under what conditions such a probiotic effect occurs and what LAB strains to use to attain this effect.

\section{CONCLUSIONS}

Results of this study indicate minimal responses in animal performance to both long- and short-term inoculation of grass silage with LAB. Dry matter intake was not affected by long- or short-term silage inoculation, nor was dietary NDF or fat digestibility or N or energy balance. Milk composition (except urea) and FPCM were not affected by long- or short-term silage inoculation, nor was milk microbial count. However, milk yield tended to be greater with long-term silage inoculation. As a result, $\mathrm{CH}_{4}$ expressed in units of grams per day, grams per kilogram of DMI, grams per kilogram of milk, or grams per kilogram of FPCM was not affected by long- or short-term silage inoculation. However, $\mathrm{CH}_{4}$ expressed in units of kilojoules per kilogram of $\mathrm{BW}^{0.75}$ per day tended to be greater with long-term silage inoculation. Strain and dose differences, compounded with different basal silages and rumen fermentation conditions, are likely responsible for the lack of significant treatment effects in the present study, although positive effects have been observed by others. Analysis of the complex interrelationships between experimental factors and cow responses would benefit from a thorough meta-analysis of the available literature to discern under what conditions a changed response can be anticipated. Ideally, such analysis would be done before further in vivo testing.

\section{ACKNOWLEDGMENTS}

This research was conducted as part of the research program Low Emission Animal Feed, initiated by the
Dutch Ministry of Economic Affairs. Their funding and the funding provided by Chr. Hansen A/S (Hørsholm, Denmark) is gratefully acknowledged.

\section{REFERENCES}

Abrahamse, P. A., J. Dijkstra, B. Vlaeminck, and S. Tamminga. 2008. Frequent allocation of rotationally grazed dairy cows changes grazing behavior and improves productivity. J. Dairy Sci. 91:20332045.

Ando, S., M. Ishida, S. Oshio, and O. Tanaka. 2006. Effects of isolated and commercial lactic acid bacteria on the silage quality, digestibility, voluntary intake and ruminal fluid characteristics. AsianAust. J. Anim. Sci. 19:386-389.

Asa, R., A. Tanaka, A. Uehara, I. Shinzato, Y. Toride, N. Usui, K. Hirakawa, and J. Takahashi. 2010. Effects of protease-resistant antimicrobial substances produced by lactic acid bacteria on rumen methanogenesis. Asian-Aust. J. Anim. Sci. 23:700-707.

Basso, F. C., A. T. Adesogan, E. C. Lara, C. H. S. Rabelo, T. T. Berchielli, I. A. M. A. Teixeira, G. R. Siqueira, and R. A. Reis. 2014. Effects of feeding corn silage inoculated with microbial additives on the ruminal fermentation, microbial protein yield, and growth performance of lambs. J. Anim. Sci. 92:5640-5650.

Bayatkouhsar, J., A. M. Tahmasebi, and A. A. Naserian. 2011. The effect of microbial inoculation of corn silage on performance of lactating dairy cows. Livest. Sci. 142:170-174.

Boeckaert, C., B. Vlaeminck, V. Fievez, L. Maignien, J. Dijkstra, and N. Boon. 2008. Accumulation of trans C18:1 fatty acids in the rumen after dietary algal supplementation is associated with changes in the Butyrivibrio community. Appl. Environ. Microbiol. 74:6923-6930.

Cao, Y., Y. Cai, T. Takahashi, N. Yoshida, M. Tohno, R. Uegaki, K. Nonaka, and F. Terada. 2011. Effect of lactic acid bacteria inoculant and beet pulp addition on fermentation characteristics and in vitro ruminal digestion of vegetable residue silage. J. Dairy Sci. 94:3902-3912.

Cao, Y., T. Takahashi, K. Horiguchi, N. Yoshida, and Y. Cao. 2010. Effect of adding lactic acid bacteria and molasses on fermentation quality and in vitro ruminal digestion of total mixed ration silage prepared with whole crop rice. Grassl. Sci. 56:19-25.

Chilliard, Y., C. Martin, J. Rouel, and M. Doreau. 2009. Milk fatty acids in dairy cows fed whole crude linseed, extruded linseed, or linseed oil, and their relationship with methane output. J. Dairy Sci. 92:5199-5211.

Contreras-Govea, F. E., R. E. Muck, D. R. Mertens, and P. J. Weimer. 2011. Microbial inoculant effects on silage and in vitro ruminal fermentation, and microbial biomass estimation for alfalfa, bmr corn, and corn silages. Anim. Feed Sci. Technol. 163:2-10.

Driehuis, F., S. J. W. H. Oude Elferink, and S. F. Spoelstra. 1999 Anaerobic lactic acid degradation in maize silage inoculated with Lactobacillus buchneri inhibits yeast growth and improves aerobic stability. J. Appl. Microbiol. 87:583-594.

Ellis, J. L., A. Bannink, I. K. Hindrichsen, R. D. Kinley, W. F. Pellikaan, N. Milora, and J. Dijkstra. 2016. The effect of lactic acid bacteria included as a probiotic or silage inoculant on in vitro rumen digestibility, total gas and methane production. Anim. Feed Sci. Technol. 211:61-74.

Ellis, J. L., J. Dijkstra, E. Kebreab, A. Bannink, N. E. Odongo, B. W. McBride, and J. France. 2008. Aspects of rumen microbiology central to mechanistic modelling of methane production in cattle. J. Agric. Sci. 146:213-233.

Fang, W., M. Shi, L. Huang, J. Chen, and Y. Wang. 1996. Antagonism of lactic acid bacteria towards Staphylococcus aureus and Escherichia coli on agar plates and in milk. Vet. Res. 27:3-12.

FAOSTAT. 2013. Food and Agriculture Organization of the United Nations, Statistics Division. Accessed June 19, 2014. http:// faostat3.fao.org/faostat-gateway/go/to/download/G1/*/E.

Fellner, V., L. E. Phillip, S. Sebastian, and E. S. Idziak. 2001. Effects of a bacterial inoculant and propionic acid on preservation of 
high-moisture ear corn, and on rumen fermentation, digestion and growth performance of beef cattle. Can. J. Anim. Sci. 81:273-280.

Fernández, L., S. Langa, V. Martín, A. Maldonado, E. Jiménez, R. Martín, and J. M. Rodríguez. 2013. The human milk microbiota: Origin and potential roles in health and disease. Pharmacol. Res. 69:1-10.

Goelema, J. O., M. A. M. Spreeuwenberg, G. Hof, A. F. B. van der Poel, and S. Tamminga. 1998. Effect of pressure toasting on the rumen degradability and intestinal digestibility of whole and broken peas, lupins and faba beans and a mixture of these feedstuffs. Anim. Feed Sci. Technol. 76:35-50.

Gollop, N., V. Zakin, and Z. G. Weinberg. 2005. Antibacterial activity of lactic acid bacteria included in inoculants for silage and in silages treated with these inoculants. J. Appl. Microbiol. 98:662-666.

Gordon, F. J. 1989. An evaluation through lactating cattle of a bacterial inoculant as additives for grass silage. Grass Forage Sci. 44:169-179.

Haigh, P. M., M. Appleton, and S. F. Clench. 1987. Effect of commercial inoculant and formic acid + formalin silage additives on silage fermentation and intake and on liveweight change of young cattle. Grass Forage Sci. 42:405-410.

Harfoot, C. G., and G. P. Hazlewood. 1997. Lipid metabolism in the rumen. Pages 382-426 in The Rumen Microbial Ecosystem. 2nd ed. P. N. Hobson and C. S. Stewart, ed. Blackie Academic \& Professional, London, UK.

Hellings, P., G. Bertha, and M. Vanbelle. 1985. Effect of lactic acid bacteria on silage fermentation. Pages 932-933 in Proc. XV Int. Grassl. Congr. Kyotosyppan, Kyoto, Japan.

Henderson, N. 1993. Silage additives. Anim. Feed Sci. Technol. 45:3556.

Hill, H. A. 1989. Microbial ecology of lactobacilli in silage. Pages 4764 in Food for Thought, Second Forage Symposium Proceedings. Pioneer Hi-Bred International Inc., Microbial Genetic Division, Johnston, IA.

Hristov, A. N., J. Oh, J. L. Firkins, J. Dijkstra, E. Kebreab, G. Waghorn, H. P. S. Makkar, A. T. Adesogan, W. Yang, C. Lee, P. J. Gerber, B. Henderson, and J. M. Tricarico. 2013. Mitigation of methane and nitrous oxide emissions from animal operations: I. A review of enteric methane mitigation options. J. Anim. Sci. 91:5045-5069.

ISO-IDF (International Organization for Standardization-International Dairy Federation). 1998. Animal feeding stuffs-Animal products, and faeces or urine - Determination of gross calorific value-Bomb calorimeter method. ISO 9831: 1998. ISO, Geneva, Switzerland.

ISO-IDF (International Organization for Standardization-International Dairy Federation). 1999a. Animal feeding stuffs - Determination of fat content. ISO 6492: 1999. ISO, Geneva, Switzerland.

ISO-IDF (International Organization for Standardization-International Dairy Federation). 1999b. Animal feeding stuffs-Determination of moisture and other volatile matter content. ISO 6496: 1999. ISO, Geneva, Switzerland.

ISO-IDF (International Organization for Standardization-International Dairy Federation). 1999c. Whole milk-Determination of milkfat, protein and lactose content-Guidance on the operation of mid-infrared instruments. ISO 9622: 1999. ISO, Geneva, Switzerland.

ISO-IDF (International Organization for Standardization-International Dairy Federation). 2002a. Animal feeding stuffs - Determination of crude ash. ISO 5984:2002. ISO, Geneva, Switzerland.

ISO-IDF (International Organization for Standardization-International Dairy Federation). 2002b. Milk fat-Determination of the fatty acid composition by gas-liquid chromatography. ISO 15884: 2002. ISO, Geneva, Switzerland.

ISO-IDF (International Organization for Standardization-International Dairy Federation). 2002c. Milk fat-Preparation of fatty acid methyl esters. ISO 15885: 2002. ISO, Geneva, Switzerland.

ISO-IDF (International Organization for Standardization-International Dairy Federation). 2004a. Milk-Determination of urea content-Enzymatic method using difference in pH. ISO 14637: 2004. ISO, Geneva, Switzerland.
ISO-IDF (International Organization for Standardization-International Dairy Federation). 2004b. Animal feeding stuffs - Enzymatic determination of total starch content. ISO 15914: 2004. ISO, Geneva, Switzerland.

ISO-IDF (International Organization for Standardization-International Dairy Federation). 2009. Animal feeding stuffs-Determination of nitrogen content and calculation of crude protein content-Part 2: Block digestion and steam distillation method. ISO 5983-2: 2009. ISO, Geneva, Switzerland.

Jalc, D., A. Laukova, Z. Varadyova, P. Homolka, and V. Koukolova. 2009a. Effect of inoculated grass silage on rumen fermentation and lipid metabolism in an artificial rumen (RUSITEC). Anim. Feed Sci. Technol. 151:55-64.

Jalc, D., Z. Varadyova, A. Laukova, P. Homolka, and F. Jancik. 2009b. Effect of inoculated corn silage on rumen fermentation and lipid metabolism in an artificial rumen (RUSITEC). Anim. Feed Sci. Technol. 152:256-266.

Jiménez, E., L. Fernández, A. Maldonado, R. Martín, M. Olivares, J. Xaus, and J. M. Rodríguez. 2008. Oral administration of Lactobacillus strains isolated from breast milk as an alternative for the treatment of infectious mastitis during lactation. Appl. Environ. Microbiol. 74:4650-4655

Keady, T. W. J., and J. J. Murphy. 1996. Effects of inoculant treatment on ryegrass silage fermentation, digestibility, rumen fermentation, intake and performance of lactating dairy cattle. Grass Forage Sci. 51:232-241.

Keady, T. W. J., and J. J. Murphy. 1997. Effects of treating low dry matter herbage with a bacterial inoculant or formic acid on the intake and performance of lactating dairy cattle. J. Anim. Sci. $64: 25-36$

Keady, T. W. J., R. W. J. Steen, D. J. Kilpatrick, and C. S. Mayne. 1994. Effects of inoculant treatment on silage fermentation, digestibility and intake by growing cattle. Grass Forage Sci. 49:284-294.

Keady, T. W. J., and W. J. Steen. 1995. The effects of treating low dry-matter, low digestibility grass with a bacterial inoculant on the intake and performance of beef cattle, and studies of its mode of action. Grass Forage Sci. 50:217-226.

Keady, T. W. J., and W. J. Steen. 1996. Effects of applying a bacterial inoculant to silage immediately before feeding on silage intake, digestibility, degradability and rumen volatile fatty acid concentrations in growing beef cattle. Grass Forage Sci. 51:155-162.

Khan, N. A., J. W. Cone, and W. H. Hendricks. 2009. Stability of fatty acids in grass and maize silages after exposure to air during the feed out period. Anim. Feed Sci. Technol. 154:183-192.

Khuntia, A., and L. C. Chaudhary. 2002. Performance of male crossbred calves as influenced by substitution of grain by wheat bran and the addition of lactic acid bacteria to diet. Asian-australas. J. Anim. Sci. 15:188-194.

Kononoff, P. J., and K. J. Hanford. 2006. Technical Note: Estimating statistical power of mixed models used in dairy nutrition experiments. J. Dairy Sci. 89:3968-3971.

Kristensen, N. B., K. H. Sloth, O. Højberg, N. H. Spliid, C. Jensen, and R. Thøgersen. 2010. Effects of microbial inoculants on corn silage fermentation, microbial contents, aerobic stability, and milk production under field conditions. J. Dairy Sci. 93:3764-3774.

Kung, L., Jr., J. H. Chen, E. M. Kreck, and K. Knutsen. 1993. Effect of microbial inoculants on the nutritive value of corn silage for lactating dairy cows. J. Dairy Sci. 76:3763-3770.

Li, Y., and Q. Meng. 2006. Effect of different types of fibre supplemented with sunflower oil on ruminal fermentation and production of conjugated linoleic acids in vitro. Arch. Anim. Nutr. 60:402-411.

Maragkoudakis, P. A., K. C. Mountzouris, C. Rosu, G. Zoumpopoulou, K. Papadimitriou, E. Dalaka, A. Hadjipetrou, G. Theofanous, G. P. Strozzi, N. Carlini, G. Zervas, and E. Tsakalidou. 2010. Feed supplementation of Lactobacillus plantarum PCA 236 modulates gut microbiota and milk fatty acid composition in dairy goats-A preliminary study. Int. J. Food Microbiol. 141:S109-S116.

Martin, C., J. Rouel, J. P. Jouany, M. Doreau, and Y. Chilliard. 2008. Methane output and diet digestibility in response to feeding dairy cows crude linseed, extruded linseed, or linseed oil. J. Anim. Sci. $86: 2642-2650$. 
Martín, R., M. Olivares, M. L. Marín, L. Fernández, J. Xaus, and J. M. Rodríguez. 2005. Probiotic potential of 3 lactobacilli strains isolated from breast milk. J. Hum. Lact. 21:8-17.

Martinsson, K. 1992. A study of the efficacy of a bacterial inoculant and formic acid as additives for grass silage in terms of milk production. Grass Forage Sci. 47:189-198.

Mayne, C. S. 1990. An evaluation of an inoculant of Lactobacillus plantarum as an additive for grass silage for dairy cattle. Anim. Prod. 39:65-76.

McAllister, T. A., L. B. Selinger, L. R. McMahon, H. D. Bae, T. J. Lysyke, S. J. Oosting, and K. J. Chang. 1995. Intake, digestibility, and aerobic stability of barley silage inoculated with mixtures of Lactobacillus plantarum and Enterococcus faecium. Can. J. Anim. Sci. 75:425-432.

McDonald, P., A. R. Henderson, and S. J. E. Heron. 1991. Additives. Pages 184-236 in The Biochemistry of Silage. 2nd ed. Chalcombe Publications, Aberystwyth, UK.

Meeske, R., H. M. Bassona, and C. W. Cruywagen. 1999. The effect of a lactic acid bacterial inoculant with enzymes on the fermentation dynamics, intake and digestibility of Digitaria eriantha silage. Anim. Feed Sci. Technol. 81:237-248.

Muck, R. E. 1993. The role of silage additives in making high quality silage. Pages 106-116 in Silage Production from Seed to Animal. NRAES-67. Northeast Regional Agric. Eng. Service, Syracuse, NY.

Muck, R. E. 2013. Recent advances in silage microbiology. Agric. Food Sci. $22: 3-15$.

Muck, R. E., I. Filya, and F. E. Contreras-Govea. 2007. Inoculant effects on alfalfa silage: In vitro gas and volatile fatty acid production. J. Dairy Sci. 90:5115-5125.

Muck, R. E., and L. Kung Jr. 1997. Effects of silage additives ensiling. Pages 187-199 in Silage: Field to Feedbunk. NRAES-99. Natural Resource, Agriculture, and Engineering Service, Ithaca, NY.

Muller, T., U. Behrendt, and M. Muller. 1996. Antagonistic activity in plant-associated lactic acid bacteria. Microbiol. Res. 151:63-70.

O'Brien, M., T. Hashimoto, A. Senda, T. Nishida, and J. Takahashi. 2013. The impact of Lactobacillus plantarum TUA1490L supernatant on in vitro rumen methanogenesis and fermentation. Anaerobe 22:137-140.

Petit, H. V., and P. M. Flipot. 1990. Intake. Duodenal flow, and ruminal characteristics of long or short chopped alfalfa-timothy silage with or without inoculant. J. Dairy Sci. 73:3165-3171.

SAS Institute. 2011. SAS 9.3 Options: Reference. 2nd ed. SAS Institute Inc., Cary, NC

Soleimani, N. A., R. K. Kermanshahi, B. Yakhchali, and T. N. Sattari. 2010. Antagonistic activity of probiotic lactobacilli against Staphylococcus aureus isolated from bovine mastitis. Afr. J. Microbiol. Res. 4:2169-2173.

Spoelstra, S. F. 1991. Chemical and biological additives in forage conservation. Pages 48-70 in Proceedings of a Conference on Forage
Conservation Towards 2000. G. Pahlow and H. Honig, ed. Gunter Pahlow, Braunschweig, Germany.

van Gastelen, S., E. C. Antunes-Fernandes, K. A. Hettinga, A. Klop, S. J. J. Alferink, W. H. Hendriks, and J. Dijkstra. 2015. Enteric methane production, rumen volatile fatty acid concentrations, and milk fatty acid composition in lactating Holstein-Friesian cows fed grass silage- or corn silage-based diets. J. Dairy Sci. 98:1915-1927. van Lingen, H. J., L. A. Crompton, W. H. Hendricks, C. K. Reynolds, and J. Dijkstra. 2014. Meta-analysis of relationships between enteric methane yield and milk fatty acid profile in dairy cattle. J. Dairy Sci. 97:7115-7132.

Van Soest, P. J. 1994. Function of the ruminant forestomach. Pages 230-252 in Nutritional Ecology of the Ruminant. P. Van Soest, ed. Cornell University Press, Ithaca, NY.

Van Soest, P. J., J. B. Robertson, and B. A. Lewis. 1991. Methods for dietary fiber, neutral detergent fiber, and nonstarch polysaccharides in relation to animal nutrition. J. Dairy Sci. 74:3583-3597.

Van Vuuren, A. M., C. J. Van Der Koelen, H. Valk, and H. De Visser. 1993. Effects of partial replacement of ryegrass by low protein feeds on rumen fermentation and nitrogen loss by dairy cows. J. Dairy Sci. 76:2982-2993.

Vandenbergh, P. A. 1993. Lactic acid bacteria, their metabolic products and interference with microbial growth. FEMS Microbiol. Rev. 12:221-238.

Wardynski, F. A., S. R. Rust, and M. T. Yokoyama. 1993. Effect of microbial inoculation of high-moisture corn on fermentation characteristics, aerobic stability, and cattle performance. J. Anim. Sci. 71:2246-2252.

Warner, D., J. Dijkstra, W. H. Hendriks, and W. F. Pellikaan. 2014 Stable isotope-labelled feed nutrients to assess nutrient-specific feed passage kinetics in ruminants. J. Sci. Food Agric. 94:819-824.

Warner, D., B. Hatew, S. C. Podesta, G. Klop, S. van Gastelen, H. van Laar, J. Dijkstra, and A. Bannink. 2016. Effects of nitrogen fertilisation rate and maturity of grass silage on methane emission by lactating dairy cows. Animal 10:34-43.

Weinberg, Z. G., G. Ashbell, Y. Hen, and A. Azrieli. 1993. The effect of applying lactic acid bacteria at ensiling on the aerobic stability of silages. J. Appl. Bacteriol. 75:512-518.

Weinberg, Z. G., and R. E. Muck. 1996. New trends and opportunities in the development and use of inoculants for silage. FEMS Microbiol. Rev. 19:53-68.

Weinberg, Z. G., R. E. Muck, and P. J. Weimer. 2003. The survival of silage inoculant lactic acid bacteria in rumen fluid. J. Appl. Microbiol. 94:1066-1071.

Zhang, S., and C. W. Maddox. 2000. Cytotoxic activity of coagulasenegative staphylococci in bovine mastitis. Infect. Immun. 68:11021108. 